Planning Perspectives

Vol. 27, No. 4, October 2012, 1-5

Routledge

Taylor \& Francis Group

Urban transformations: booms, busts and other catastrophes: 11th Australasian Urban History/Planning History Conference, Perth, 2012

\author{
Caryl Bosman ${ }^{\mathrm{a} *}$ and Ruth Fazakerley ${ }^{\mathrm{b}}$ \\ ${ }^{a}$ Urban Research Program, Griffith University, Queensland, Australia; ${ }^{b}$ School of Architecture \& \\ Design, RMIT University, Melbourne, Australia
}

\title{
Introduction
}

The 11th biennial Australasian Urban History/Planning History (AUHPH) Conference was held in two venues in Perth, Western Australia, from 5 to 8 February 2012. The convenors, Jenny Gregory and Andrea Gaynor from the University of Western Australia and Sarah McQuade from the State Library of Western Australia, ably assisted by Elizabeth Gralton, designed a high-quality programme that included eminent and highly acclaimed academics, historians, and urban history/planning history enthusiasts from a wide range of disparate disciplines. Significantly, the programme also included a number of excellent postgraduate presentations which launched or further established these researchers as significant contributors to the field of urban/ planning history. The organising committee is to be congratulated on delivering a stimulating, collegial and enjoyable conference that was efficiently administered.

\section{Overview of the conference series}

The AUHPH series evolved from a conference on critical urban biography organised by Robert Freestone (University of New South Wales, Sydney) and held in Sydney in 1993. Since then it has become a biennial event with an established name, format, and reputation, catering to scholars of urban/planning history across multiple disciplines. The conferences have been held in capital and regional cities across Australia and New Zealand, each reliant upon the goodwill of a particular individual to convene the event and manage the associated costs. As Petrow states, 'No society has been established ... to run the UHPH conference. There are no office bearers and no common source of funding to draw on'. 'This informal arrangement has resulted in a fabulously diverse conference programme and venue location. Partly due to the informal structure, participants (delegates and non-delegates) have varied widely in number and academic focus and the papers presented similarly reflect a wide range of topics. The conference supports and fosters postgraduate students and Early Career Researchers as well as being a respected venue for veteran researchers to network and present their latest research. The drawstring that ties the AUHPH conference together and makes it such a success is the participants' passion for urban/planning history in all its guises: from the theoretical to the practical, from the social through to the physical and the environmental, from the local to the global, and everything in-between.

\footnotetext{
*Corresponding author. Email: c.bosman@griffith.edu.au
} 


\section{AUHPH 2012}

The theme of this year's Australasian AUHPH conference was 'Urban Transformations: booms, busts and other catastrophes'. Perth, along with many other cities world wide, was built, and is still being built, on the back of a series of economic booms. These periods of growth are tied into the city's 'history as a resource and energy capital' (http://www.uhph2012.com). The conference sub-themes picked up on the drivers of many urban transformations: economic prosperity, the Global Financial Crisis, and flood, cyclone, earthquake and other natural disasters. The focus on these themes allowed conference participants to reflect upon 'the complex, interwoven histories of cities and their environments' (http://www.uhph2012.com).

The conference was accompanied by an exhibition of the same name at the State Library of Western Australia, showcasing real estate posters, architectural drawings, photographs, and other records relating to Perth's planning and architecture, drawn from the holdings of the Library and State Records Office. The conference programme began with the screening of archival films about Perth and the building of suburbia, together with an informal reception. Produced between 1959 and 1970, at which time the West Australian Government was actively seeking migrants, largely from England, the films told a story about Perth's ongoing suburban development, from the clearance of pristine native bushland on sand dunes to the creation of residential housing estates.

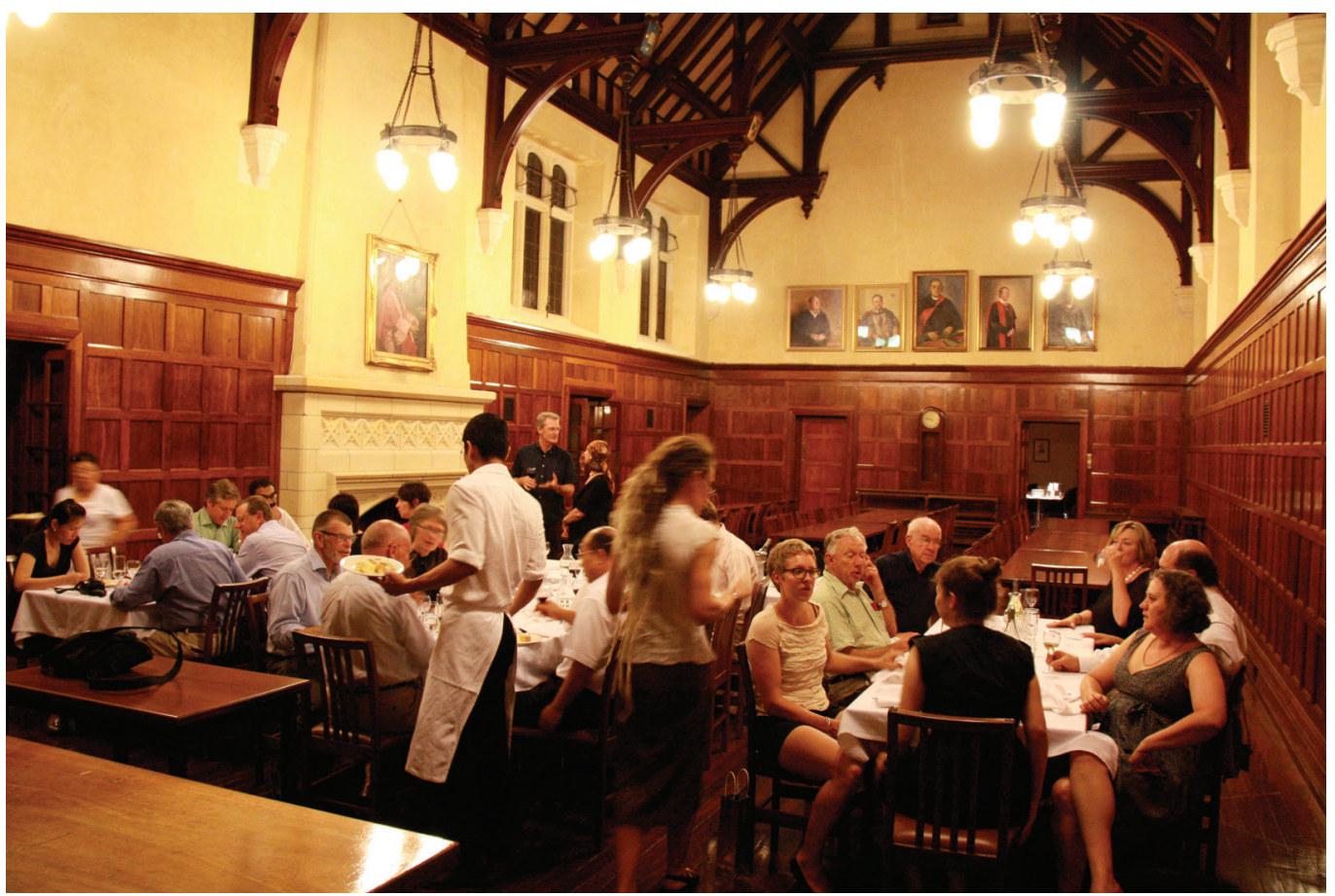

Figure 1. AUHPH conference dinner, St George's college dining hall, University of Western Australia, February 2012. 
The Hon John Day, Minister for Planning, Culture and the Arts, Science and Innovation in Western Australia, formally opened the conference, while the Lord Mayor of Perth, the Right Honourable Lisa Scafiddi, welcomed delegates at a reception in Council House, an exemplar of modernist architecture (Howlett and Bailey Architects, 1963) saved from demolition in the 1990s. The conference dinner was also held in a notable local building, the historic St George's College dining hall (Hobbs, Smith \& Forbes, 1931) at the University of Western Australia (Figure 1). The evening was a great success, the food and wine were excellent and conference participants had the opportunity to socialise and network with colleagues and AUHPH veterans as well as newer converts. The culminating event of the conference was a bus tour to Fremantle, via Perth's western suburbs, highlighting the rich history and diversity of the city's fabric. The conference organisers also made available a post-conference walking tour revealing the neglected heritage of central Perth (Figure 2).

\section{Keynote speakers}

Richard Weller, Winthrop Professor of Landscape Architecture, The University of Western Australia, presented an engaging account of some of the landmark projects and controversies with which he has been involved throughout his career, including work with Daniel Liebeskind's architectural studio in Berlin, the design of the Garden of Australian Dreams for the National Museum

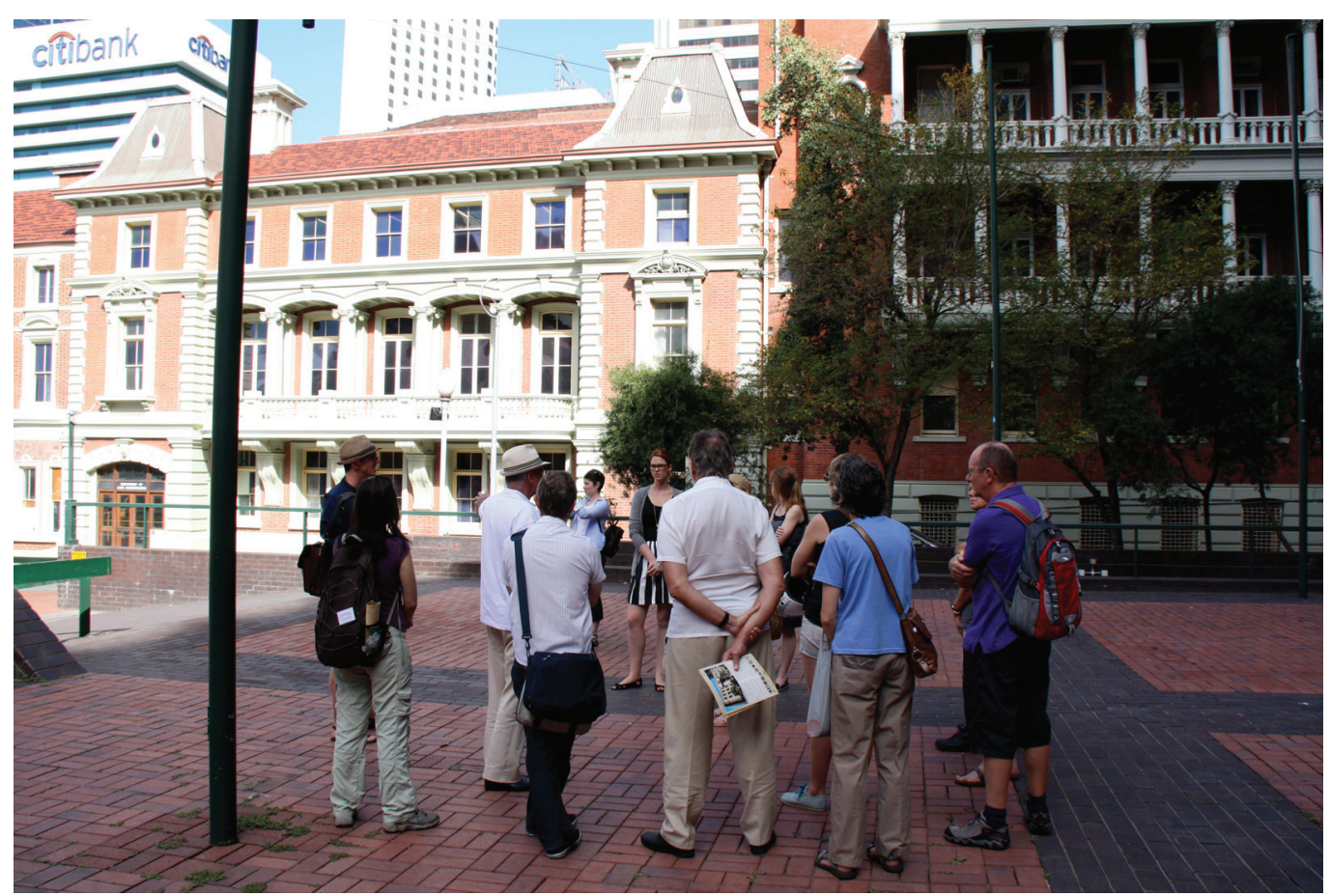

Figure 2. AUHPH conference walking tour February 2012 led by Richard Offen. 
in Canberra (see http://www.nma.gov.au/about_us/the-building), and his current designs for the contentious Perth Waterfront Project (see http://www.mra.wa.gov.au/Projects/Perth-Waterfront/ About-the-Project/). From the perspective of a design practitioner, working within the exigencies of budgets, client, and stakeholder demands, Weller emphasised the importance of prioritising the public realm and of engaging with the past to design for the present.

The second keynote address, presented by Charles Schencking, Associate Professor of History, Hong Kong University, recalled the events of the 1923 Tokyo and Yokohama earthquake and subsequent fires. The fires destroyed $45 \%$ and $90 \%$, respectively, of Tokyo and Yokohama's urban space, killing over 100,000 people in total. Schencking outlined the opportunities that paradoxically emerged for urban planning and design from this catastrophe, as well as the political, fiscal, and socio-cultural difficulties of operationalising those opportunities. Both keynote speakers were engaging and informative and both illustrated the links between urban/planning histories and contemporary concerns and practices.

\section{Concurrent sessions and panel discussions}

Scheduled over two and a half days, 42 presentations were distributed across loosely themed concurrent sessions of three speakers each. The following account gives some indication of the diversity of presentations.

Papers on day one ranged from Chris Berry's examination of the transformations of metropolitan Perth's local governance during the colonial gold rush, to Simone Sharpe's study of the impact of domestic appliance manufacturing in transforming urban and suburban post-war Melbourne, and Arun Chandu's insightful history of the Woodland's real estate project, also in Melbourne. Caroline Miller's presentation concerning the role of planning history in contemporary planning education drew attention to its particular relevance when dealing with presentday catastrophes such as the Christchurch earthquakes. The day included a panel discussion drawing upon the rich local expertise of Simon Holthouse (former chair of the Western Australian Planning Commission), Martyn Webb (Emeritus Professor of Geography), and Tony Brand (architect), to reflect on Perth's planning and architecture since the 1950s. Issues concerning the current Perth Waterfront Project were hotly debated, neatly dovetailing with matters raised in Weller's keynote address that followed.

Day two began with allied presentations on monuments and memorials. Quentin Steven's research on public memorials reminded us of the critical relationship between planning strategies and built form, specifically in relation to social meanings and behaviours. Neil Foley's study of Gilbert Rotton, an early colonial surveyor working in Perth, illustrated how urban planning has come full circle: from Rotton's late1880s, simple grid plan that was walkable and included mixed land-uses; to an intermediate period of 'no planning'; to the Western Australian Government's present day 'Liveable Neighbourhoods' operational policy that reiterates much of Rotton's ideas and practices. Seamus O'Hanlon presented a beguiling story linking post-WWII Jewish immigrants in Melbourne to the local property market in apartment buildings. His research revealed how individual migrants have prospered and, in doing so, have contributed significantly to the shape and form of the city's urban landscape. Andrew May's presentation on the urban iconography of letterhead designs, culled from archival municipal correspondence in Melbourne, likewise reminded us of the complicated and complex webs that inform our urban environments. 
Day three saw the conference move to the Crawley campus of The University of Western Australia. The morning's papers engaged variously with diverse approaches to urban design; from the colonial town grid to the city street, from the rural settlement to the urban fringe. The formal presentations concluded with a panel discussion offering perspectives upon the history and prospects of the field of urban history/planning history. Rob Freestone presented his 'unreliable memoirs' concerning the history of the AUHPH conferences since 1993, while Jenny Gregory noted the growing diversification and multi-disciplinarity of approaches to undertaking urban history, and the kaleidoscopic variety of subjects and themes being examined, at both micro and macro scales. She went on to identify issues and trends currently affecting the field, notably the predominance of descriptive Australian studies that seem to have poor recognition by scholars outside of Australia. Peter Spearritt argued for the need to take better advantage of conferences, such as the AUHPH conference, and the networks they provide to more widely promote the impartial expertise of academics and their role in tackling major urban issues. Like Gregory, Spearritt pointed to the opportunities (and need) for more comparative analytical studies.

\section{Summary and where to next?}

Future conferences will no doubt match the high quality of the Perth conference and its predecessors. The intention is to further build upon the conference's current inclusive approach to postgraduate scholars by means of additional targeted sponsorship, research training, and networking events. The next AUHPH Conference will be held in February 2014 in Wellington, New Zealand. The School of Architecture, Victoria University of Wellington will host the event. To stay informed about developments and for further information see the Australasian Urban History/Planning History Group at http://uhphg.com.

\section{Notes on contributors}

Caryl Bosman is a senior lecturer in Urban and Environmental Planning. Her current research interests focus on suburban histories and the planning and provision of housing for an ageing population, particularly in relation to ideals of community, 'the good life' and placemaking.

Ruth Fazakerley is a researcher in the School of Architecture and Design, RMIT University, engaged as part of a major project investigating the impact and reception of contemporary art, including memorials, in urban public spaces. Her research focuses on the disciplinary histories of public art and urban design and the relations between them.

\section{Note}

1. S. Petrow, 'Conference Report', Town Planning Review 81, no. 4 (2010): 467. 